\title{
ANALYSIS OF THE INSUFFICIENT IMPLEMENTATION OF THE BASIC INSTRUMENTS OF INTERNET MARKETING IN THE BANKING SECTOR OF MONTENEGRO
}

\section{ANALIZA NEDOVOLJNE PROVEDBE OSNOVNIH INSTRUMENATA IN- TERNET MARKETINGA U BANKARSKOM SEKTORU CRNE GORE}

\author{
Biljana Rondovic, Dijana Kovacevic, Tamara Djurickovic \\ Faculty of Economics, University of Montenegro, Podgorica, Montenegro \\ Ekonomski fakultet, Sveučilište Crne Gore, Podgorica, Crna Gora
}

\section{Abstract}

In this paper, the authors have critically explored the level of use of internet marketing in the banking industry, conducted an analysis of the current situation, set out the reasons calling for a more comprehensive implementation of internet marketing techniques and identified factors which affect the selection of their optimum combination. For the purposes of this analysis, we have used qualitative research based on a semi-structured in-depth interview. Qualitative research conducted on a sample of 19 representatives of banks. In addition to these type of surveys, an analysis and evaluation of the websites banks was carried out as well, based on the Web Assessment Index (WAI), whereas the Facebook Assessment Index (FAI) method was used for assessing the effects of using Facebook (as the quintessential representative of social networks). The results indicate that internet marketing has vast potential in the banking industry, that the potential of various instruments of internet marketing are not the same and that there are numerous limitations to their implementation banks. This paper aims to use the obtained results to help the banks' employees and management recognize and consider the potential of internet marketing at a more profound level and properly adapt the selected combination of instruments to different client profiles. The identified barriers to the implementation of this marketing concept in Montenegrin banks may provide a basis for seeking solutions for their removal, and thus, in the final part of the paper, in addition to reflecting on the identified problems, the authors put forward their recommendations and
Sažetak

U ovom radu autori su kritički istraživali razinu korištenja internet marketinga $\mathrm{u}$ bankarskoj industriji, proveli analizu trenutačne situacije, postavili razloge koji zahtijevaju sveobuhvatniju implementaciju internetskih marketinških tehnika i identificiranih čimbenika koji utječu na odabir njihove optimalne kombinacije. Za potrebe ove analize koristili smo kvalitativno istraživanje temeljeno na polustrukturiranom dubinskom intervjuu. Kvalitativno istraživanje provedeno je na uzorku od 19 predstavnika banaka. Uz ove vrste anketa provedena je analiza i evaluacija banaka web stranica, temeljena na indeksu procjene weba (WAI), dok je metoda Facebook procjene procjene (FAI) korištena za procjenu učinaka upotrebe Facebooka (kao suštinskog predstavnika društvenih mreža). Rezultati pokazuju da internet marketing ima ogroman potencijal u bankarskoj industriji, da potencijal različitih instrumenata internet marketinga nije isti i da postoje brojna ograničenja za njihovu implementaciju u bankama. Ovaj rad ima za cilj koristiti dobivene rezultate kako bi zaposlenicima i menadžmentu banaka prepoznali i razmotrili potencijal internet marketinga na dubljoj razini te pravilno prilagodili odabranu kombinaciju instrumenata na različite profile klijenata. Identificirane prepreke provedbi ovog marketinškog koncepta u crnogorskim bankama mogu pružiti osnovu za traženje rješenja za njihovo uklanjanje, pa će u konačnom dijelu rada, osim razmišljanja o identificiranim problemima, autori predočiti svoje preporuke i prijedloge. Rezultati analize mogu poslužiti kao literarna baza za usporednu analizu 
suggestions. Results of the analysis can serve as a literary base for the comparative analysis of this kind in developing countries, such as Montenegro.

\section{Introduction}

Even in the early 1990s, the commercialization of the Internet fostered awareness of its marketing potential. An insight into the scientific and technical papers written on internet marketing provides the identification of four lines of thought on the impact of the Internet on marketing practices:

- The pioneering work in this area treated the Internet as a platform for interactivity and authors took the attitude that it could be seen as a new uniquely applicable marketing channel /1/;

- Somewhat later, Venkatraman /2/ held the view in his work that the Internet completely changed the concept of marketing and put the legitimacy of the existence of traditional marketing into question;

- Porter $/ 3 /$, as a representative of the third line of thought, adopts a more moderate attitude and states that, within Information and Communication Technology (ICT), the Internet supports existing marketing approaches and increases the potential of traditional marketing;

- Representatives of the modern holistic school /4/ considers interactivity a basic feature of the Internet, but also notes that it is not uniquely applicable and that it must be observed in a variety of contexts of engagement between all market participants.

The terms e-marketing, internet marketing, interactive marketing and online marketing are very often regarded as synonyms, both in theory and in practice. We believe that the definition depends upon the angle authors take when they address a problem, as well as on the background of the problem, the specialization of the author and so on. We have provided an answer to the question whether the aforementioned terms should be treated as synonyms in the chapter Literature Review by acknowledging the previous professional contributions of a substantial number of authors. We as the authors take the attitude that internet marketing can now be observed as one part of electronic marketing aimed at attaining marketing goals by using internet technology, but ove vrste $u$ zemljama u razvoju, kao što je Crna Gora.

we also hold the opinion that the interconnection between all ICT resources, including the Internet, other networks, databases, consumer behavior management systems, various applications, mobile devices and others, will make it even harder to differentiate between these terms in the future. In that, on the one hand, our own opinion is that banks in Montenegro are rather passive when it comes to the use of internet technology for implementing marketing activities, and, on the other hand, based on the information that there is an increase in the number of internet users who seek interactivity on the so-called permission access, we believe that a study such as this will both bear scientific relevance and provide benefits to business practice.

\section{Research Objectives}

In accordance with the above-stated ideas, the following objectives have been set by the research:

- Determining whether, and to what extent, internet marketing is implemented by Montenegrin banks,

- Establishing whether the results of users response prompted by implementing internet marketing activities are measurable;

- Identifying the factors that hinder the process of the integration of internet marketing strategies into the structure of overall marketing activities;

- Developing recommendations for further actions in this field with the aim of improving marketing tools by using internet technologies, and

- Determining whether employees in the marketing sectors of Montenegrin banks utilize information on certain demographic characteristics of the population (gender, age, income, education, employment and territorial affiliation), experience in the use of the Internet, the loyalty to the bank, and so on, when creating the marketing mix in a digital environment.

Montenegro belongs to the group of small countries, so the fact that only 12 commercial banks operate in its territory does not mean that there is no tough competition between them. Bearing this 
in mind, we believe that the adequate implementation of internet marketing in the process of attracting and retaining customers can be a powerful competitive weapon. Furthermore, aware of the problem that most Montenegrin banks employ marketing experts who attended traditional marketing schools, we felt that a study like this may offer a deeper comprehension of this problem and put a different perspective on the way in which marketing activities are conducted. In addition to this, this study may provide a basis for further quantitative research in terms of providing empirical evidence on the importance of marketing activities on the internet in the Montenegrin banking sector. Since Montenegro belongs to the group of smaller developing countries of South-East Europe, the results of this analysis may be used in certain comparative analyses which go beyond national borders.

\section{Literature Review}

A review of the relevant literature indicates that, when it comes to this issue, there is a problem in defining the notion of electronic marketing. As a result, a number of researchers consider the terms e-marketing, internet marketing, interactive marketing and online marketing to be equivalent. They justify such an attitude by the fact that all these phenomena have one thing in common, which is the use of ICT in the process of informing, attracting and retaining users. On the other hand, many researchers are inclined to think that the use of different ICT resources in the implementation of marketing activities allows for different interpretations of these terms. The first works that dealt with the importance of ICT in marketing were composed before the real commercialization of the Internet, and thus, logically, these works dealt with automatic and electronic data processing for the purposes of marketing sectors /5/. The research studies /6/ conducted later emphasize the connection between marketing and management information systems, i.e. their reporting functions. Papers written in the early 1990s feature limited research due to doubts that the authors of that period harbored regarding the real possibilities of the Internet $/ 7 /$. It was not before the late 1990s, that the analysis of contemporary marketing tools took on a different dimension with works of Samiee /8/, Wientzen /9/ and others. Even in this relatively early period, papers specifically dealing with interactive marketing
/10/ and digital marketing /11/ can be found and somewhat later, papers dealing with internet marketing /12/ and online marketing /13/. Nowadays, with the development of mobile phone technology, the term mobile marketing is increasingly used as well. In later studies, the focus has shifted from different conceptual definitions to the identification of differences between traditional and internet marketing.

There certainly are differences between these forms of marketing, but underestimating traditional or overestimating new forms of marketing should be avoided /14/. The paper Direct and Interactive Marketing explores four key features of internet marketing, which indicate how this type of marketing differs from the classic marketing /15/:

1. Both classic and internet marketing are based on information, but internet marketing relies on more extensive and more detailed information due to more comprehensive databases, technologies for contact with customers and means of monitoring customer behavior;

2. An important feature of internet marketing is interactivity, or the two-way process of communication, transactions and customer relations management,

3. Internet marketing is characterized by a higher degree of measurability of the effects of the marketing activities, which should be the ultimate aspiration of every marketing expert and

4. Due to its interactivity, internet marketing is more likely to draw a direct response to the implemented forms of marketing activities.

In addition to the comparison of traditional and electronic marketing, Mangles /15/ dealt with quantitative evidence of the effects that occur in B2B markets, depending on whether traditional or electronic marketing activities were applied.

Related to these comparisons is the review of the transformation of the marketing mix (from traditional to contemporary theory). The research paper Study on Combining of E-commerce and Emarketing /16/ indicates how the concept of the marketing mix has evolved since the 1950s through:

- $\quad 4 \mathrm{P}$ (Product, Price, Promotion, Place)

- $\quad 4 \mathrm{C}$ (Consumer's needs, Cost, Communication, Convenience) 
- 4R (Relevance, Reaction, Relationship, Reward)

- $\quad 4 \mathrm{~S}$ (Scope, Site, Synergy, System)

Although this transformation took place by virtue of the Internet and internet marketing, it indubitably affected and enhanced the classical theories of marketing. Recent studies have been less concerned with the rivalry between traditional and electronic marketing and the focus has shifted to the potential of electronic marketing, and to exploring and considering those factors which affect it and the effects of its implementation. In this regard, this study has been driven by the results presented in several papers, from various industry branches, for different markets.The empirical research carried out for the Chinese market has shown that the success of internet marketing is not always guaranteed and that its potential is influenced by such factors as awareness of the site, site attractiveness, promotional effectiveness, the effectiveness and shopping impacts and the effectiveness and loyalty of the success of electronic marketing /17/. Research exploring the impact of online marketing on user satisfaction in the computer industry of Malaysia has drawn similar conclusions, where the authors came to the conclusion that there is a significant correlation between electronic marketing and customer loyalty /18/. The study Understanding the Effects of Market Orientation and E-marketing on Service Performance aims to use the interrelationship between market orientation and e-marketing in order to explore alternative mechanisms by means of which both contribute to tourism service performance $/ \mathbf{1 9} /$. If a company uses the mechanisms of confidence boosting, then it can enjoy multiple benefits from the services it provides on the electronic market /20/. A study conducted in Finland has indicated that internet marketing has great potential in the tourism industry in particular and that the users' replies to the implemented marketing techniques are almost immediately visible and measurable /21/. Unlike papers which assess the potential of internet marketing in terms of the company, a somewhat smaller number of papers direct their research focus on customer perception. Postmodern marketing research in the context of consumers has yielded interesting results /22/. The paper The Logic of Electronic Markets has presented the Internet as an enabling tool, which allows direct, real-time individualized interaction with postmodern consumers. For marketers, both in academia and in practice, the pow- er of the Internet as a marketing tool within the postmodern consumer context needs to be continually evaluated and exploited. The paper Internet Marketing and Customer Satisfaction in Emerging Markets: the Case of Chinese Online Shoppers provides some fascinating insights into the factors that moderate the level of customer satisfaction among Chinese online shoppers. These are likely to become important determinants of the success (or failure) of companies' customer satisfaction management programs related to online shopping in China and, therefore, of practical value to companies engaging in internet marketing $/ 23 /$. In most of the works, the new "marketing formula" refers to the joint creation of unique value with customers and personalization. Under the new approach, consumers play an ac-

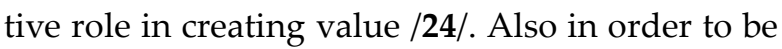
market orientated implies that the firm embraces a strategy to obtain and use information about the environment and to disseminate this information throughout the firm $/ 25 /$. We have noticed that in the available literature there are a very few studies which focus on systematic empirical research into the impact of internet marketing activities on the effects of business operation, and that there are no papers investigating those effects in time series. This review of selected elements of the literature indicates that internet marketing can strengthen the relationship between companies and customers, but also that companies should be wary of a combination of internet marketing techniques, since different categories of users do not respond to the same brand message design or to the same means of its placement. Moreover, the explored papers point to the conclusion that without a well-defined internet marketing plan and adequately implemented internet marketing strategies, no e-marketing tool guarantees improvement in performance marketing. The role of the consumer could be very important in driving these technologies forward /26/. It should be borne in mind that the mistaken selection of internet marketing techniques or their poor implementation may inflict more damage than a strategy of not implementing internet marketing at all. An insight into the available literature has led us to conclude that there are no comprehensive studies focusing on the analysis of the level of implementation and the potential of internet marketing in the banking sector, either from the perspective of the bank or the user. This was an additional 
incentive to undertake a study on this topic covering the Montenegrin banking sector.

\section{Research methodology, research tools and char- acteristics of the sample}

Due to the nature of the problem which is the subject of our work, we decided to carry out the research in three independent stages, and then to integrate the generated results.

The first stage of the research study was qualitative. In this stage of the research, the sample comprised representatives of employees in the Marketing Departments of various Montenegrin banks (a total of 12 participants from commercial banks and a representative from the Central Bank of Montenegro), 3 representatives of consulting and marketing agencies and 3 web designers. This stage of the research was carried out by employing the method of an in-depth, semi-structured interview. We chose this research method in order to gain a better insight into the attitude of marketers towards both the current and potential implementation of internet marketing and to identify any facts which may have been overlooked in the quantitative research. In the second stage, the results of testing the quality of the websites of Montenegrin banks generated by the Web Assessment Index (WAI) method were added to the previously conducted qualitative research study. The WAI model was developed in 2001 and so far it has been used in a number of studies aimed at assessing the quality of websites of companies in different branches of industry. This model was later successfully used in evaluations of the quality of bank websites $/ \mathbf{2 7} /, \mathbf{2 8} /$, so for this reason we decided to adopt this model in our study. The quality of the Montenegrin banks' websites was rated based on four criteria: accessibility, access speed, navigability and site content. In terms of sub-criteria, we used search engine presence and link popularity to rate access. We decided to rate the search engine presence by using Google, and to measure the link popularity by using data obtained from the AlexaWebsite. In order to measure access speed we undertook an independent test rating the speed of opening of the banks' website pages from one computer at the same time. The testing was repeated 3 times in the span of 15 days and we obtained results with negligible difference. To test navigation, we used the subjective view of the author, assessing the presence of site maps, the ease of navigation, links between the homepage and other pages of the site, how users find the navigation through the site and so on.

In order to evaluate content, on the basis of previously conducted studies, we divided the criteria into three sub-categories:

1. Information content (general information about the bank, information on products and services, information on prices)

2. Content related to communication with customers (address, phone, e-mail, fax and User Feedback options)

3. Content related to the transactions itself .

Out of a total of 100 points for evaluating the quality of the site, 55 was assigned to content (on the subjective view as the most important criterion for evaluating the quality of the site), and 15 points was provided for access, speed and navigation respectively. Out of the 15 points provided for access, 5 points was awarded for search engines presence, and 10 points for the number of site visits.

In the third stage, we tested the effects of the performance of Montenegrin banks as part of social networks by using the Facebook Assessment Index (FAI). In accordance with the previous quantitative evaluation of websites conducted using the Web Assessment Index, we used Facebook Assessment Index (FAI) to assess the effects of using Facebook (as the quintessential representative of social networks in Montenegro). FAI was first proposed by $/ 29 /$, for the purposes of assessing the effects of the use of Facebook for 200 international banks. The assessment was undertaken on the basis of three indicators: Popularity, Interactivity and Content. Since the subject matter of our research corresponds to the problems explored in the aforementioned study, we used the same indicators as the authors who developed the FAI method to assess the effects of the use of Facebook. Likewise, in order to calculate the final index value, we used the formula the abovementioned authors came up with in their research. The test was conducted three times over the span of one month and once we had concluded that no significant changes in the results occurred in different assessment periods, we completed the third rating. We used the number of followers on the Facebook page of each bank to evaluate popularity, whereas we used 5 proposed indicators to assess interactivity: 
- The number of wall posts made by the organization in the previous 7 days.

- The average number of "likes" per post (based on the 10 most recent posts).

- The average number of comments per post (based on the 10 most recent posts).

- The average number of shared posts (based on the 10 most recent posts).

- The average number of users' posts answered by the company in less than 24 hours (based on the 10 most recent posts in which an answer was demanded).

For evaluating the quality of the content we used the twenty two indicators recommended (bank information, video, product information, photos, corporate identity, other Facebook pages, marketing messages, claims and suggestions, events, charity events, polls, web site, external links, Scommerce application, location, coupons or specific offers, phone, gamification apps/contest, email, downloads, contact form and careers)

The final index value was obtained by the formula:

FAI $=\mathrm{w} 1 \times$ Popularity Value $+\mathrm{w} 2 \times$ Interactivity Value $+w 3 \times$ Content Value

According to the importance of indicators for assessing the effects of the use of Facebook on a 0 to 100 scale, popularity accounted for $25 \%$ (w1), interactivity for $40 \%$ (w2) and content for $35 \%$ (w3). Having collected and processed the data according to a pre-defined plan, we began interpreting the research results. For the purpose of writing the paper, we relied on the basic theoretical methods, appropriate for the social sciences: definition, classification, induction, deduction, analysis and synthesis.

\section{Results and discussion}

Although electronic banking is the most developed segment of e-business in Montenegro, it is still too early to talk about a satisfactory level of internet banking (as part of e-banking), and a satisfactory level of internet marketing (as part of e-marketing). In all banks in Montenegro the image of innovation is important, the technology is available and the package of services which should be made more familiar to customers is more or less the same. For all of them, internet marketing is recognized as an essential instrument for attracting and retaining customers, but still not as a top priority activity type within their overall marketing activities.

What follows is an outline of the problems detected and certain illogicalities which hinder the profiling of internet marketing in Montenegro.

Analysis of the effects of use of Web Sites as instruments of electronic marketing

From interviews with competent people from the marketing sector (subsequently confirmed by the authors' observations) one gets the impression that all the banks have invested maximum efforts in the design and operation of their websites and that, in terms of quality, they do not lag behind the websites of banks operating in developed market economies. Nevertheless, after performing a quantitative evaluation through the application of the Web Assessment of Index (WAI), it was clear that deficiencies exist and that much is to be done to enhance their functionality and brand image.

After completing the assessment the following results were obtained:

- Out of the possible total of 100 points, only one Montenegrin bank had between 80 and 90 points, three banks were in the range of 70-80, 2 banks in the range of 60-70, one bank in the range of 50-60 and as many as 5 banks had below 50 points,

- When analyzing the presence of the banks on the web browser, we used the keywords: credit, credit cards, interest rates and money transfers. None of the banks have more than 60 hits, 4 banks have between 50 and 60 hits, 7 banks have between 30 and 50 hits, and one bank fewer than 30.

- By measuring the speed of access, we found the quickest access being 1,18 seconds, and the slowest 5.9 seconds. We also noted that the access speed is directly correlated with the amount of information contained on the site.

- We have seen that banks with a better score as regards access have better navigation as well.

- In terms of website content, all the banks received the maximum number of points for informative content and the content related to contact information and communication. A very small number of points was awarded on the basis of the content related to online transactions and information about the implemen- 
tation of online transactions, which leads us to the conclusion that the level of online transactions is still not particularly high. In terms of the assessment of the quality of the content, 6 banks were awarded between 40 and 50 points, 2 banks between 30 and 40 points and 2 banks between 20 and 30 points, while 2 banks received fewer than 20 points. The websites of all Montenegrin banks are available in both English and Montenegrin.

Showing derived estimates is given in Table 1 and correlation coefficients in Table 2.

\begin{tabular}{|c|c|c|c|c|c|c|c|c|c|c|c|c|c|}
\hline \multirow[b]{2}{*}{ Banks } & \multicolumn{3}{|c|}{ Accessibility } & \multicolumn{2}{|c|}{ Access spead } & \multicolumn{3}{|c|}{ Navigability } & \multicolumn{4}{|c|}{ Site Content } & \multirow[b]{2}{*}{$\begin{array}{c}\text { Sum } \\
\text { (max } \\
100)\end{array}$} \\
\hline & $\begin{array}{c}\text { engine } \\
\text { presence }\end{array}$ & $\begin{array}{c}\text { link } \\
\text { popularity }\end{array}$ & $\begin{array}{c}\text { Sum } \\
(\max 15)\end{array}$ & seconds & $\begin{array}{c}\text { Sum } \\
(\max 15)\end{array}$ & $\begin{array}{c}\text { site } \\
\text { maps } \\
(10)\end{array}$ & $\begin{array}{c}\text { keyword } \\
\text { s (5) }\end{array}$ & $\begin{array}{c}\text { Sum } \\
(\max 15)\end{array}$ & $\begin{array}{c}\text { Informati } \\
\text { on } \\
\text { content } \\
\text { (20) }\end{array}$ & $\begin{array}{c}\text { Commun } \\
\text { ication } \\
\text { content } \\
\text { (15) }\end{array}$ & $\begin{array}{c}\text { Transacti } \\
\text { ons } \\
\text { content( } \\
20)\end{array}$ & $\begin{array}{c}\text { Sum } \\
(\max 55)\end{array}$ & \\
\hline Bank 1 & 4,5 & 9,3 & 13,8 & 1,29 & 13,0 & 5 & 3,40 & 8,4 & 19 & 14 & 11 & 44,0 & 79,2 \\
\hline Bank2 & 2,9 & 8,4 & 11,3 & 2,57 & 10,0 & 0 & 2,50 & 2,5 & 17 & 7 & 20 & 44,0 & 67,8 \\
\hline Bank 3 & 1,4 & 7,6 & 9,0 & 1,38 & 13,0 & 3 & 2,30 & 5,3 & 14 & 14 & 14,4 & 42,4 & 69,7 \\
\hline Bank 4 & 2,4 & 7,8 & 10,2 & 2,11 & 11,0 & 7 & 3,70 & 10,7 & 18 & 15 & 12 & 45,0 & 76,9 \\
\hline Bank 5 & 1,8 & 9,5 & 11,3 & 2,24 & 11,0 & 2 & 3,50 & 5,5 & 19 & 15 & 20 & 54,0 & 81,8 \\
\hline Bank 6 & 0,2 & 4,0 & 4,2 & 1,21 & 12,0 & 2 & 0,54 & 2,5 & 11 & 11 & 9 & 31,0 & 49,7 \\
\hline Bank 7 & 1,3 & 8,7 & 10,0 & 5,90 & 8,0 & 0 & 0,98 & 1,0 & 18 & 12 & 15 & 45,0 & 64,0 \\
\hline Bank 8 & 1,6 & 2,0 & 3,6 & 1,22 & 13,0 & 0 & 0,96 & 1,0 & 11 & 9 & 11 & 31,0 & 48,6 \\
\hline Bank 9 & 0,2 & 1,0 & 1,2 & 3,34 & 9,0 & 4 & 0,77 & 4,8 & 14 & 9 & 11,5 & 34,5 & 49,5 \\
\hline Bank 10 & 3,5 & 4,0 & 7,5 & 1,25 & 13,0 & 3 & 2,30 & 5,3 & 20 & 14 & 15 & 49,0 & 74,8 \\
\hline Bank 11 & 0,9 & 1,0 & 1,9 & 1,69 & 12,0 & 2 & 0,70 & 2,7 & 12 & 9 & 8 & 29,0 & 45,6 \\
\hline Bank 12 & 2,3 & 6,6 & 8,9 & 1,18 & 13,0 & 0 & 2,21 & 2,2 & 9 & 8 & 6,5 & 23,5 & 47,6 \\
\hline
\end{tabular}

Table 1. Quality rating websites of Montenegrin banks using WAI index.

Accessibility Access speed Navigability Site Content

\begin{tabular}{lllll}
\hline \hline AccessibilityT & 1.000000 & 0.293375 & 0.821995 & 0.985329 \\
Access spead & 0.293375 & 1.000000 & 0.030316 & -0.806179 \\
Navigability & 0.821995 & 0.030316 & 1.000000 & 0.8907128 \\
Site Content & 0.985329 & -0.806179 & 0.8907128 & 1.000000
\end{tabular}

Table 2. Correlation coefficients.

From the simple correlation analysis we can see that a strong correlation exists between Accessibility and Navigability $(0,821)$, nearly perfect positive correlation between Accessibility and Site Content $(0,985)$ and relatively high degree of correlation between Navigability and Site Content (0.907). Also, the analysis showed that there is a high negative correlation between the Site Content and Access speed (-0.806). From the simple correlation analysis we can see that a strong correlation exists between Accessibility and Navigability $(0,821)$, nearly perfect positive correlation between Accessibility and Site Content $(0,985)$ and relatively high degree of correlation between Navigability and Site Content (0.907). Also, the analysis showed that there is a high negative correlation between Site Content and Access speed (0.806). The analysis of the obtained evaluation suggests that marketing experts in Montenegrin banks should invest more effort in improving the functionality of their websites. This primarily refers to a more serious approach to the SEO technique to maximize visibility. It also means increasing the quality of the website content as regards online transactions that can be offered to customers, increasing the quality of navigation, more prompt updating of the information available and a higher level of incentive as regards customer interactivity. From our interviews with respondents, we concluded that none of the marketing sectors of the Montenegrin banks that were subject to our research has performed any market research whatsoever, something which would have provided useful data to help create strategies for their web presentations. Based on their answers, we also concluded that the majority of 
Montenegrin banks do not use systems for measuring the statistics of visits to their websites. This approach is in line with the initial attitude of the respondents that the banks' websites in Montenegro are still not used as a primary channel for transactions and customer service.

If we bear in mind the fact that banks in developed market economies have long viewed marketing performance through the website as a serious task, so that banks develop methodologies for monitoring the results of these activities, and that these banks have a growing army of satisfied customers which subsequently reflects on the banks' business as well as the fact that a large number of banks are opening sectors for e-business (including electronic marketing activities), then we must conclude that the approach of Montenegrin banks to this problem is passive if not inert.

Analysis of the effects of the use of social networks as instruments of electronic marketing

Out of the total of 12 banks analyzed, 10 feature links to social networks on their websites (mainly to Facebook), while the remaining two plan to add this feature in the next few months. Those banks that have accounts on social networks generally post about their activities, products, services, their commitment to corporate social responsibility and so on Still, there have been very few specific marketing campaigns via social networks. Only one respondent said that the bank where they work is planning to hire new personnel who will be committed exclusively to fullfledged marketing activities on social networks. Other employees in the marketing sector were of the opinion that social networks, which they regard as insufficiently serious, might jeopardize the image of the bank as a serious partner.

When we asked the question of how banks keep track of the effects of their activities on social networks, we got the same answer - based on the number of followers. This kind of response convinced us of the correctness of our initial opinion that our respondents have a very superficial understanding of the potential of social networks, the type of expected presence in the community and the ways of exploiting the large amounts of data that can be obtained via social networks. The ability to advertise on Facebook requires the need to measure the effectiveness of this form of online advertising. For measuring the efficiency of online advertising various methods are used from simple metrics (like cost per click, cost per impression or click-through rate) to more complex statistical methods (e.g. data envelopment analysis or stochastic frontier modeling) using statistical software $/ \mathbf{3 0}$. . After completing the assessment via the Facebook Assessment Index (FAI), we received results which could hardly be called encouraging. The final value of the index for all the banks in which we measured the effects of their presence on Facebook ranged from 20 to 35 (Table 3). When assessing popularity we noticed that the banks have very different numbers of followers, which ranges from 100 to 1000 . If we know that many international banks have over 30,000 followers, then we can only conclude how little employees in the marketing sectors of Montenegrin banks work on strategies to increase their number of followers. With a low number of followers a bank cannot count on a high level of communication.

As regards interactivity, the results were also not encouraging.

- The average number of wall posts for nine banks is lower than 2 , and for one bank only it is slightly higher than 3,

- The average number of "likes" per post does not exceed 700,

- The average number of comments per post for nine banks is fewer than 5, and for only one bank is slightly higher than 7 ,

- The average number of shared posts by Montenegrin banks is under 3 ,

- Only one bank responds to user posts within 24 hours, while all other banks respond with a somewhat greater delay.

The results obtained by assessing the content were slightly better than those obtained by assessing popularity and interactivity. Through the analysis of this indicator it can be concluded that the banks offered pretty much every form of informative content and that all the contact and communication information is on the website. In addition, we noticed a lack of content related to money transfers and e-commerce as well as that none of the banks have yet allowed access to applications or a document download facility via Facebook. 
The absence of a section where clients can upload their suggestions and complaints gives the impression that the banks fear the public multiplication of information that they evidently feel could be damaging to the operation of the bank.
In addition, three banks offer information on Facebook on the need for new staff, but vacancies are still announced and applications submitted by means of conventional recruitment procedures.

\begin{tabular}{|l|r|r|r|r|}
\hline FB page & Index popularity & Index interactivity & Index content & Ukupno \\
\hline Bank1 & 1,38 & 1,34 & 27,53 & 30,25 \\
\hline Bank2 & 2,15 & 0,71 & 23,40 & 26,26 \\
\hline Bank3 & 4,28 & 5,54 & 17,21 & 27,03 \\
\hline Bank4 & 4,60 & 5,72 & 1,07 & 31,39 \\
\hline Bank5 & 11,78 & 4,31 & 18,21 & 35,38 \\
\hline Bank6 & 2,64 & 1,24 & 19,29 & 22,09 \\
\hline Bank7 & 5,77 & 1,28 & 17,86 & 21,48 \\
\hline Bank8 & 2,56 & 1,06 & 16,31 & 20,32 \\
\hline Bank9 & 2,50 & 1,51 & 27,86 & 29,72 \\
\hline Bank10 & 0,94 & 0,92 & 15,00 & 24,10 \\
\hline Bank11 & 5,10 & 4,00 & 18,57 & 20,24 \\
\hline Bank12 & 1,05 & 0,62 & & 19 \\
\hline
\end{tabular}

Table 3. Quality rating appearances on social networking sites using FAI index.

From the Figure 1 shows that all the criteria are positively correlated, as was expected. Note that the highest degree of correlation exists between the criteria of popularity and interactivity, while slightly lower between popularity and content. That brings us to the fact that those banks which through its Facebook page More interact with users and have more quality content, ie. relevant information, they also have a greater number of followers who expect benefits from defining these Facebook page. We can also notice that there is a negligible link between interactivity and content, which is understandable, because if the site has good content, it does not mean that you will achieve and good communication with customers, and vice versa.

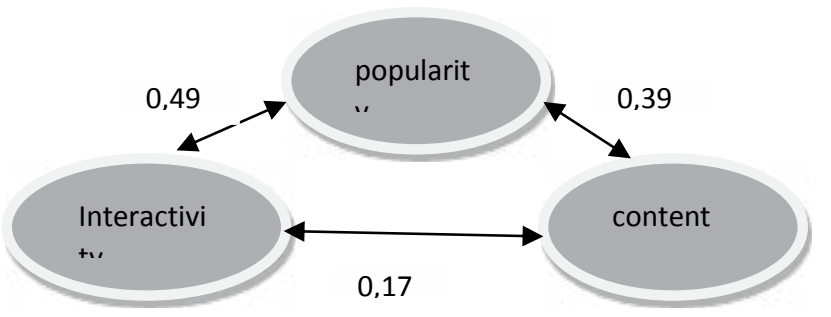

Figure 1. Correlation between criteria interactivity, popularity and content.

The resulting final value of the Facebook Assessment Index shows that Montenegrin banks have a sufficient degree of maturity for participation in social networks. The reasons for the low scores recorded here should be sought in insufficiently trained marketing staff who cannot use the new tools of the digital economy, in the low level of the Internet marketing budget as a proportion of the total budget for marketing activities, as well as in the (lack of) support from the bank management, the lack of awareness of the importance and potential of this internet marketing strategy, the 
absence of online activities strategies and various other factors. Furthermore, comparisons of ratings with the WAI and FAI, we further found that there is a positive correlation between them.
Height WAI monitors the height of the FAI, which we still lead to the conclusion that activities on the Web related to the scope of activities the bank conducts on social networks.

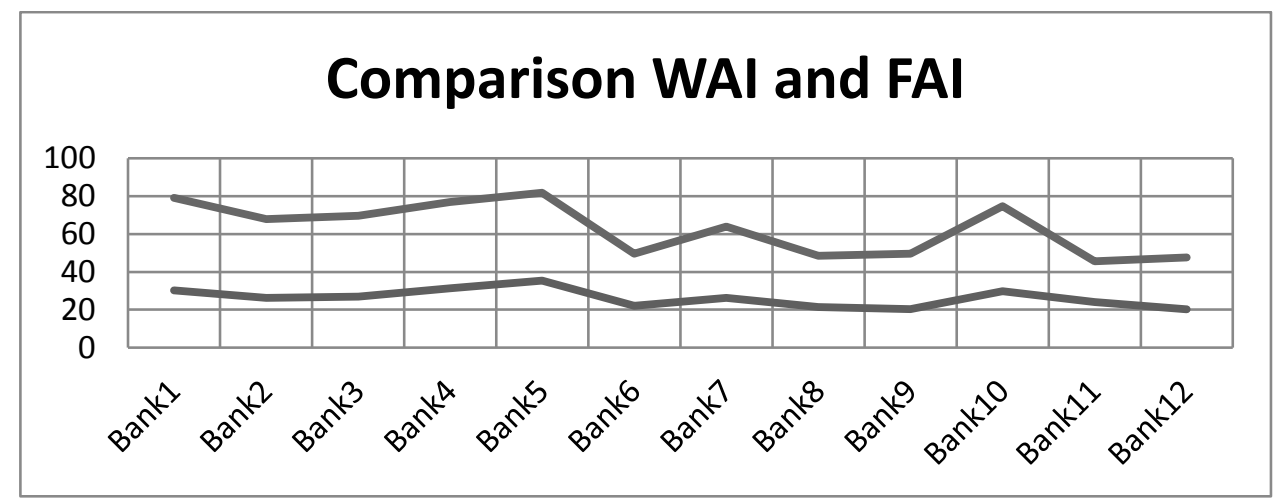

Figure 2. Comparison of WAI and FAI

Analysis of the effects of the use of e-mail as instruments of electronic marketing

The schemes created by employees in the marketing sectors for electronic marketing are often equated with internet marketing. All the country's banks periodically use e-mail marketing campaigns. The survey results also show that all the respondents are of the opinion that e-mail marketing can produce a high response rate, that it is an inexpensive promotional channel, and that it can yield good results, regardless of the tactics applied in its implementation. However, when we asked the following questions: Do you plan e-mail marketing strategy in your marketing sector? Do you study clients' profiles before sending email messages? Do you have a methodology for measuring the response of users? Do you take into consideration the potential errors of antispam programs and the possibility that due to these a number of messages end up as spam? When sending e-mail messages do you consider the possibility that a user whose e-mail address is used to send the message will take that as an abuse of personal data? Do you implement any tactics which might suggest to the client that the message has been personalized to a certain level? - to provide only some examples,- we received exclusively negative answers. Additionally, respondents did not have a unified position on the issue of the content, form and length of such emails. The different views of people who are engaged in the same kind of business, for the same branch of industry with the same character of products and services and targeting similar user profiles lead us to conclude that prior to the implementation of email activities, these marketing experts did not consult any professional literature related to this area and that activities are simply carried out on a case-by-case basis.

Analysis of the effects of discussion groups as an instrument of electronic marketing

Although, from the client's standpoint discussion groups may offer valuable information on banking services, pricing, procedures, opinions of other group members and other issues, no Montenegrin bank is currently present on any forum for the purposes of promotional activities. Such a passive attitude towards this instrument of online marketing is justified by employees in the marketing sectors by the fact that information on banks placed on the forums would be considered as non-serious, as well as by the view that participation in the forums requires a sustained commitment from someone who would deal exclusively with this kind of work, and which would still not yield benefits. When we asked them whether they had conducted any market research that could prove that they cannot reach their target groups through forums, we got a negative response. All the respondents are of the opinion that activities on internet forums will not be considered as an online marketing strategy in either the short or medium term. We believe that the three analyzed 
online marketing strategies are implemented haphazardly in all the banks and that with such an approach Montenegrin banks cannot expect online marketing to have positive effects in the long run. Overall, if we take into account the results of various surveys carried out on this subject across the world on the one hand /31/, and examine the views of marketing experts in Montenegrin banks and the effects of their online marketing activities on the other, and then add the results of the assessment conducted for the purpose of this study, it is not difficult to conclude that the level of online marketing capabilities in Montenegrin banks is very low. There is strong competition among Montenegrin banks and it is obvious that employees in the marketing sectors, in order to gain competitive advantages, are currently focused on finding new products and services, while devising strategies for the bank's website presentation, forums, social networks and so on is, in the case of 9 out of 12 banks, left at least in part to the IT sector, where logically enough there is a lack of interdisciplinary knowledge.

Without wishing to criticize the existing marketing practices, we still have to conclude that for the time being, Montenegrin banks have not recognized the role of the multi-channel integration of sales, marketing and ICT resources. We must also conclude that the struggle for long-term financial sustainability has not started in the marketing sectors in any of the analyzed banks.

The impression of the authors is that marketing experts use all the instruments of online marketing only to encourage customers to come into the bank branch itself, which is still considered to be the safest environment for transactions. Such a situation is, among other things, the consequence of the very low level of application of online banking in Montenegro.

\section{Conclusion}

The analyses conducted for this study reveal that marketing professionals are familiar with the technology that can be used in the field of online marketing, but they do not have sufficient knowledge for their operational use. The analyses show that the perception of employees in the marketing sectors differs from the assessment we obtained by testing websites for quality, testing of the effects of banks' operation via social networks and indeed the subjective assessment of the authors. In the marketing sectors of the analyzed banks, there is still no awareness that without the continuous use of new instruments and a wellplanned marketing policy, the bank's activities in the field of attracting and retaining customers in the near future could be called into question. We believe that, as time passes, customers' expectations will increasingly move towards aspirations for greater simplicity, more sophisticated services, and higher speeds of access to information and increasingly personalized online communication. Therefore, the key people in the marketing sector should be aware that simply adopting new technologies, without their serious operational use, is already inefficient and that in the future it will be even less so.

This serious operational use, among other things, requires:

- The adaptation of traditional marketing programs to the new instruments of the digital environment,

- The expertise of marketing staff and management being adapted to the potential of the online environment,

- The definition of criteria for the successful implementation of online marketing activities,

- The permanent monitoring of customer requirements, and accordingly, replacing intuitive analysis by analyses based on micro segmentation,

- Using the benefits of the existence of "a large number of data" that can be obtained using modern instruments of marketing,

- Promotion of the instruments of online marketing among customers,

- Using the experience of successful banks from developed market economies and the elimination of "bottlenecks" in the marketing practice of Montenegrin banks,

- Developing an effective methodology for measuring the success of internet marketing strategies

- On the basis of what has been said so far, it can be concluded that the use of internet resources is not especially popular as regards the implementation of marketing activities in Montenegrin banks. One gets the impression that by remaining tied to standard marketing techniques, marketing experts want to send a mes- 
sage to their customers that their bank is a conservative and safe partner and that there is a concern that a massive use of internet marketing tools might call that image into question.

- We believe that the results of the analysis can be a good basis for marketing experts when considering the future course of action in the field of internet marketing. The analysis done can serve employees in the marketing sectors of Montenegrin banks, allowing them to draw conclusions on what the expectations and requirements of the banks' clients are, as well as which facts should be taken into account when considering future strategies for the bank's online presentation. The results obtained by processing the survey largely coincide with those obtained through other types of testing conducted for this study. Therefore, we consider that these can be used in the marketing sectors as relevant evidence to prompt future activities in the field of electronic marketing.

\section{Limitations of the research}

- Since this is the first investigation into the degree of the implementation of electronic marketing in Montenegro, the authors faced the problem of a lack of data from earlier periods and it was not possible to perform an assessment of the speed of implementation of online marketing activities over a longer period of time. Accordingly, it was impossible to make certain projections and forecasts.

- Nevertheless, despite the above limitations, we believe that this analysis can be a useful basis for future quantitative studies in terms of empirical measurements of the interdependence of individual techniques of internet marketing as well as indicators of the success of the business operation of banks.

\section{Notes}

/1/ S. Ghosh (1998), Making business sense of the internet, Harvard Business Review, March/April, pp 127135.

/2/ N. Venkatraman (2000), Five Steps to a Dot-Com Strategy: How to Find Your footing on the Web, Sloan Management Review, Spring, Voll. 41, Iss. 3, pp 15-28.

/3/ M. Porter (2001), Strategy and the Internet, Harvard Business Review, March, pp 63-78.
/4/ G. Tsekouropoulos; Z.Andreopoulou; C.Koliouska; T. Koutroumanidis; C. Batzios; P. Lefakis (2012), Marketing policies through the internet: the case of skiing centers in Greece. Scientific, Bulletin-Economic Sciences, 11(1), pp 66-78.

/5/ T. W. Malone; J.Yates; R. I. Benjamin (1987), Electronic markets and electronic hierarchies, Communications of the ACM, 30(6), pp 484-497.

/6/ T. W. Malone (1990), Organizing information processing systems: Parallels between human organizations and computer systems, Cognition, Computation and Cooperation, pp 56-83.

17/ R. A. Peterson; S. Balasubramanian; B. J. Bronnenberg (1997), Exploring the implications of the Internet for consumer marketing, Journal of the Academy of Marketing science, 25(4), pp 329-346.

/8/ S. Samiee (1998), The internet and international marketing: is there a fit?, Journal of Interactive Marketing, 12(4), pp 5-21.

19/ H. R. Wientzen (2000), What is the Internet's impact on direct marketing today and tomorrow?, Journal of Interactive Marketing, 14, pp 74-78.

/10/ Z. Luo; L. Zhou; Q. Ge (2014), The Research on Internet Marketing Performance Evaluation of Commercial Banks in 2014, International Conference on e-Education, e-Business and Information Management, Atlantis Press, (ICEEIM 2014).

/11/ K. Cox (2002), Internet marketing. Prentice Hall PTR

/12/ H. Armesh; H. Salarzehi; N. M. Yaghoobi; A. Heydari; D. Nikbin (2010), The effects of security and privacy information on trust \& trustworthiness and loyalty in online marketing in Malaysia, International Journal of Marketing Studies, 2(2), 223.

/13/ Peterson, Balasubramanian, Bronnenberg (1997), Exploring the implications of the Internet for consumer marketing, Journal of the Academy of Marketing science, 25(4), pp 329-346.

/14/ N. Venkatraman (2000), Five Steps to a Dot-Com Strategy: How to Find Your footing on the Web, Sloan Management Review, Spring, Voll. 41, Iss. 3, pp 15-28.

/15/ M. Omar; I. Bathgate; S. Nwankwo (2011), Internet marketing and customer satisfaction in emerging markets: the case of Chinese online shoppers. Competitiveness Review: An International Business Journal, 21(2), pp 224-237.

/16/ J. Chavan (2013), Internet banking-benefits and challenges in an emerging economy, International Journal of Research in Business Management, 1(1), pp 19-26.

/17/ S. Arya (2013), The role of Internet marketing in Finnish tourism industry, Laurea University of Applies Sciences, Kerava

/18/ Z. Luo; L. Zhou; Q. Ge (2014), The Research on Internet Marketing Performance Evaluation of Commercial Banks, 2014 International Conference on e-Education, e-Business and Information Management (ICEEIM 2014), Atlantis Press 
/19/ R. H. Tsiotsou; M. Vlachopoulou (2011), Understanding the effects of market orientation and emarketing on service performance, Marketing Intelligence E Planning, 29(2), pp 141-155.

/20/ M. Bulearca; S. Bulearca (2010), Twitter: a viable marketing tool for SMEs. Global Business and Management Research, An International Journal, 2(4), pp 296-309.

/21/ N. Venkatraman (2000), Five Steps to a Dot-Com Strategy: How to Find Your footing on the Web, Sloan Management Review, Spring, Voll. 41, Iss. 3, pp 15-28.

/22/ Kimiloglu (2004), The "E-Literature": A Framework for Understanding the Accumulated Knowledge about Internet Marketing, Academy of Marketing Science Review

/23/ R. Varadarajan; M. S. Yadav (2009), Marketing strategy in an internet-enabled environment: a retrospective on the first ten years of JIM and a prospective on the next ten years, Journal of Interactive Marketing, 23(1), pp 11-22.

/24/ S. Sehhat (2012), An empirical survey to measure the impact of different factors on the success of electronic marketing, Management Science Letters 2.6., 2187-2192.

/25/ M. Lewrick; M. Omar; R. L. Williams Jr. (2001), Market orientation and innovators' success: An exploration of the influence of customer and competi- tor orientation, Journal of technology management $\mathcal{E}$ innovation, 6(3), pp 48-62.

/26/ S. Saunders; M. Ross; G. Staples; S. Wellington (2006), The software quality challenges of service oriented architectures in e-commerce, Software Quality Journal, 14(1), 65-75.

/27/ M. Omar; I. Bathgate; S. Nwankwo (2011), Internet marketing and customer satisfaction in emerging markets: the case of Chinese online shoppers, Competitiveness Review: An International Business Journal, 21(2), pp 224-237.

/28/ S. Arya (2013), The role of Internet marketing in Finnish tourism industry, Laurea University of Applies Sciences, Kerava

/29/ F. J. Miranda; A. Chamorro; S. Rubio; V.Morgado, (2013), Evaluation of Social Networks Sites in the Banking Sector: An Analysis of Top 200 International Banks, Journal of Internet Banking and Commerce, 18(2), pp 1-18.

/30/ J. Chavan (2013), Internet banking-benefits and challenges in an emerging economy, International Journal of Research in Business Management, 1(1), 1926.

/31/ P. Singh; D. Kumar (2014), Impact of Internet Banking on Customer, International Journal of Research, 1(4), 394-413. 